\title{
Bacteria Incorporated Concrete
}

\author{
M V Seshagiri Rao ${ }^{1}$ and V Srinivasa Reddy ${ }^{2 *}$ \\ ${ }^{1}$ Department of Civil Engineering, CVR COE, Hyderabad, India \\ ${ }^{2}$ Department of Civil Engineering, GRIET, Hyderabad, India
}

Submission: December 17, 2017; Published: February 28, 2018

*Corresponding author: V Srinivasa Reddy, Department of Civil Engineering, GRIET, Hyderabad, India, Email: vempada@gmail.com

\section{Opinion}

The idea of self-healing phenomenon, in repairing cementitious materials itself without human interference, has been proposed and been studying for a longtime. Research on bacteria incorporated concrete, conducted at JNTU Hyderabad; realize the prospective of the bio-inspired self-healing phenomenon as innovative method of crack remediation and also in enhancing durability of concrete. In concrete structures, presence of the micro-cracks will affect its visual appearance and also its strength and durability performance. Methods currently used for crack-remediation often use organic synthetic polymers which are expensive, incompatible and aesthetically unpleasant particularly in repairing historic monuments. Because of these disadvantages of chemical surface treatments, attention has been drawn toward bacteria incorporated concrete, an alternative technique for the improvement of the mechanical and durability properties of concrete. The pioneering research was conducted on self-healing phenomena in bio-concrete by $\mathrm{V}$ Ramakrishnan, Sookie S Bang et al. at South Dakota School of Mines and Technology, USA. Willem De Muynck, Nele De Belie, Willy Verstraete, Kim Van Tittelboom et al. at Ghent University, Belgium and Henk M. Jonkers et al. at Delft University of Technology, Netherlands has studied extensively on the selfhealing capability of bacteria induced cementitious materials. In India, P. Ghosh, S. Mandal, B.D. Chattopadhyay et al. of Jadavpur University, Kolkata; V Achal, Abhijeet Mukerjee, Rafat Siddique et al. of Thapar University, Patiala, and M V Seshagiri Rao , V Srinivasa Reddy et al. of Jawaharlal Nehru Technological University Hyderabad have done extensive research on the development of high performance self-remediating bacterial concrete. Researchers around the world started working on the use of specific bacteria in cementitious materials to self-heal and seal cracks without human intervention. Though it is reported that the use of specific alkaliphilic mineral forming bacteria enhances the properties of cement mortar but there exists little understanding of the effect of bacteria on the mechanical and durability properties of concrete. This paper is aimed to presents the findings of investigations on the properties of self- healing concrete based on microbiologically induced calcite precipitation by Bacillus subtilis]C3. Bacteria integrated selfcrack-healing concrete is formed by incorporating Bacillus subtilisJC3 spore suspended nutrient-rich water to the concrete environment during the mixing phase of concrete. When cracks occur, water enters the crack and germinates the dormant bacterial spores into metabolically-active and highly alkaline resistant endospores which will precipitate insoluble white crystalline calcium carbonate minerals. Continual precipitation of bacteria produced minerals seal off the cracks and pores thereby restoring the integrity of the damaged concrete structure. Modifying the structure, distribution and connectivity of pores by biologically deposited calcite crystals have a great influence on the concrete strength and durability. This phenomenon of bacteria producing calcite crystals during its multistep microbial chemical reactions is called 'Microbiologically Induced Calcium Carbonate Precipitation (MICP)'. Bacillus subtilis through nitrogen cycle metabolically precipitates calcium carbonate crystals by oxidative de-amination of amino acids (ammonification process). The present work reports the investigations on the effect of bacteriogenic calcinosis on the mechanical and durability properties of bacteria incorporated concrete mixes of compressive strength range between 20 and $80 \mathrm{MPa}$. The optimum cell concentration of 105 cells $/ \mathrm{ml}$ of mixing water is used in the preparation of bacterial concrete. The incorporation of bacteria Bacillus subtilis]C3 (105 cells per ml) found to increase compressive strength, split tensile strength by 16 to $29 \%, 14$ to $23 \%$ respectively and the increase of flexural strength is about 19 to $31 \%$ for concretes' of strength range between 20 and $80 \mathrm{MPa}$. This improvement in strengths are due to mineral deposition within the pores of cement-sand matrix, making the concrete dense by modifying the pore structure which is characterized using scanning electron micrograph (SEM) and $\mathrm{x}$-ray diffraction analyses. The stress values are found to be high in bacteria incorporated concrete grades than conventional concrete grades when compared at the identical strain levels. Durability studies showed that, the percentage of weight loss and the percentage of strength loss in bacteria incorporated 
concrete are comparatively less than the conventional concrete when subjected to aggressive chemical attack, sulphate attack test and sea water attack substantiating the better durability performance of bacteria incorporated concrete in aggressive environments. Reduction in chloride permeability values during rapid chloride penetration test indicates that bacteria induced concrete has shown higher resistance against the chloride ion penetration than conventional concrete due to minimum interconnecting voids present. It was established through accelerated corrosion test that bacteria incorporated concrete will have the higher resistance to corrosion than conventional concrete. Water permeability test demonstrate that bacterial concrete was less permeable than conventional concrete due to improved pore structure as a result of precipitation of calcite crystals. Reduction in water permeability of specimens treated with bacteria is nearly $88 \%, 86 \%, 75 \%$ and $66 \%$ in concretes' of strength range between 20 and $80 \mathrm{MPa}$ at 28 days age of curing. Water absorption capacity (WAC) of bacteria incorporated concrete specimens is reduced by nearly 50 to $75 \%$ for low to high strength concretes as compared with WAC of controlled concrete specimens due to pore plugging with bacteria produced calcite minerals thereby modifying the pore structure of the cement - sand matrix. Porosity of concrete specimens is reduced by nearly $34-73 \%$ with induction of bacteria into concrete for high to low strength concretes. Volume of permeable voids present in bacteria incorporated concrete is less by $50-65 \%$ than in controlled specimens. The reduction in capillary due to induction of bacteria into concrete specimens is between 9 to $27 \%$ for high to low grades. The water absorption, capillary and porosity characteristics indirectly reflect the durability performance of the bacteria incorporated concrete.
Pore structure analysis using BET Nitrogen adsorption test designate that there is significant decrease in total pore volume and average pore diameter of bacteria incorporated concrete. Porosity in bacteria incorporated concretes is reduced by 20 to $60 \%$ for low to high strength concretes. Total Pore volume in bacteria incorporated concretes is reduced by 20 to $60 \%$ for low to high strength concretes. The resistance to freezing/thawing and drying/wetting of bacteria incorporated concrete is found to be considerably superior to conventional concrete when referred to percentage loss of compressive strength and percentage loss of weight after the exposure. After 28 cycles of freeze-thaw, the compressive strength loss in controlled concrete specimens is in between 8.1 to $46.4 \%$ and in bacteria incorporated concrete specimens is in between 4.7 to $17.5 \%$ as the strength of concrete increases from 20 to $80 \mathrm{MPa}$. Temperature studies on bacteria incorporated concrete specimens exhibited much better resistance to elevated temperatures up to $600{ }^{\circ} \mathrm{C}$. It is observed that bacteria incorporated specimens performed better than controlled concrete specimens up to $400{ }^{\circ} \mathrm{C}$ but at $600{ }^{\circ} \mathrm{C}$ their performance is inferior to controlled concrete specimens due to decomposition of bacteria precipitated calcite crystals.

In summary, bacteriogenic calcite mineral precipitation using Bacillus subtilis]C3 mechanism can be used effectively in improving the properties of concrete. This positive impact on both strength and durability properties can be attributed to the activity of Bacillus subtilisJC3 in development of dense and refined microstructure of bacteria incorporated concrete. This application of bio-mineralization in concrete can be considered as a best environmental friendly bio-based durable self -crack remediation technique for Indian conditions.

This work is licensed under Creative

Commons Attribution 4.0 License

DOI: 10.19080/CERJ.2018.03.555621

\section{Your next submission with Juniper Publishers} will reach you the below assets

- Quality Editorial service

- Swift Peer Review

- Reprints availability

- E-prints Service

- Manuscript Podcast for convenient understanding

- Global attainment for your research

- Manuscript accessibility in different formats

(Pdf, E-pub, Full Text, Audio)

- Unceasing customer service

Track the below URL for one-step submission https://juniperpublishers.com/online-submission.php 